\title{
Role of feeding in growth and photophysiology of Myrionecta rubra
}

\author{
Matthew D. Johnson*, Diane K. Stoecker
}

Horn Point Laboratory, University of Maryland, Center for Environmental Science, Cambridge, Maryland 21613, USA

\begin{abstract}
Myrionecta rubra is a cosmopolitan estuarine and neritic ciliate, known to cause 'redwater' blooms. The current study was conducted to achieve a better understanding of the relationship of photosynthetic performance and growth with feeding on cryptophyte algae in $M$. rubra. During the experiment the cryptophyte Teleaulax acuta was introduced for 2 consecutive growth periods (14 d each) and the cultures were then starved during 4 additional periods. In both high light (HL) and low light (LL) treatments, a significant decrease in per capita growth rates $(\mu)$ was observed over time $(\mathrm{p}<$ $0.05)$ in the absence of new prey. In the LL treatment, chlorophyll a content (chl $a$ cell $\left.^{-1}\right)$, photosynthetic capacity $\left(P_{\max (\text { cell })}\right)$, and photosynthetic efficiency $\left(\alpha_{\text {cell }}\right)$ increased after feeding and then declined during starvation. In the HL treatment, chl cell ${ }^{-1}$ and $\alpha_{\text {cell }}$ also increased and then declined after feeding; however, $P_{\max (\text { cell) }}$ showed only a slight decrease with starvation. In both treatments, $M$. rubra appeared to undergo an acclimation-like response following declines in chl cell ${ }^{-1}$, with increases in $P_{\max (c h l)}$ and the light saturation parameter $\left(I_{k}\right)$. While photosynthetic efficiency declined during starvation, overall photosynthetic capacity appeared to become uncoupled with growth over time. M. rubra demonstrated a high capacity for chl production ( 7 to $10 \mu \mathrm{g} \mathrm{chl} \mathrm{a} \mathrm{ml}{ }^{-1} \mathrm{~d}^{-1}$ ) after feeding, which decreased during starvation. Declines in growth and photosynthetic parameters coincided with the loss of prey nuclei from $M$. rubra cells, implicating a possible functional role for retained prey nuclei. These data show that $M$. rubra can function phototrophically for extended periods without ingesting prey, but that feeding is periodically required for optimal growth and photosynthesis, especially in high light.
\end{abstract}

KEY WORDS: Myrionecta rubra · Mesodinium rubrum · Teleaulax acuta - Ciliate · Organelle sequestration $\cdot$ Kleptoplastidy $\cdot$ Mixotrophy

\section{INTRODUCTION}

Myrionecta rubra (= Mesodinium rubrum) (Lohmann, 1908, Jankowski 1976) (Mesodiniidae: Litostomatea) is a common phototrophic ciliate found in pelagic estuarine and neritic habitats (Taylor et al. 1971, Lindholm 1985, Crawford 1989). Blooms or 'red tides' caused by M. rubra are recurrent events in numerous estuarine, lagoonal and coastal upwelling zones around the world, sometimes expanding for hundreds of square kilometers (Lindholm 1985). While these blooms are nontoxic, they may induce hypoxia (Hayes et al. 1989), and on rare occasions have caused crustacean and mollusk kills during near-shore accumulations, perhaps through irritation of gill tissue (Horstman 1981). Bloom dynamics of M. rubra are well studied and populations may undergo diel vertical migrations to exploit nutrient-rich water masses (Lindholm et al. 1990), optimal light levels (Passow 1991), and to maintain their retention within embayments (Crawford \& Purdie 1992). M. rubra has extraordinarily high swimming speeds for a protist, capable of bursts of speeds over $8 \mathrm{~mm} \mathrm{~s}^{-1}$ or nearly 200 body lengths $\mathrm{s}^{-1}$ (Lindholm 1985, Crawford \& Purdie 1992) and diurnal vertical migrations of $40 \mathrm{~m}$ (Smith \& Barber 1979). Discrete deep layers of M. rubra have been shown to occur in the Baltic (Setälä \& Kivi 2003) and Mediterranean (Dolan \& Marrasé 1995) seas to depths greater than $80 \mathrm{~m}$.

Myrionecta rubra has long been an evolutionary curiosity, possessing cryptophycean organelles, in- 
cluding plastids, mitochondria (Taylor et al. 1969, 1971), and sometimes nuclei (Hibberd 1977, Oakley \& Taylor 1978). Gustafson et al. (2000) demonstrated that M. rubra feeds on cryptophyte algae to sequester organelles and to maintain enhanced photosynthetic and growth rates. Although $M$. rubra feeds to acquire its plastids, its physiology drastically differs from that of other plastid sequestering ciliates. While plastid retaining oligotrich ciliates also require light for growth, they are unable to grow phototrophically (i.e. without prey) due to large heterotrophic requirements for growth (Stoecker et al. 1988, Putt 1990). In contrast, M. rubra has long been considered a functional phototroph because of its ability to form blooms, utilize dissolved inorganic nutrients (Packard et al. 1978, Wilkerson \& Grunseich 1990), and its high photosynthetic rates associated with bloom events. Stoecker et al. (1991) found a large range, 1.8 to $8.6 \mathrm{pg} \mathrm{C} \mathrm{(pg} \mathrm{chl} \mathrm{a)}{ }^{-1}$ $\mathrm{h}^{-1}$, of photosynthetic rates for $M$. rubra in estuaries and salt ponds in Falmouth, Massachusetts. While much lower rates have been measured for cultured Antarctic $M$. rubra, 0.12 to 0.22 pg C (pg chl a $)^{-1} \mathrm{~h}^{-1}$ (Gustafson et al. 2000), these measurements were made at non-saturated photosynthetic irradiance levels $\left(\sim 30 \mu \mathrm{E} \mathrm{m} \mathrm{m}^{-2} \mathrm{~s}^{-1}\right)$ and low temperatures $\left(\sim 5^{\circ} \mathrm{C}\right)$. Although feeding has been shown to greatly enhance growth rates of $M$. rubra (Gustafson et al. 2000, Yih et al. 2004), it remains unclear as to how long $M$. rubra is able to grow or persist without ingesting cryptophyte prey or how its photophysiology is related to feeding and starvation. Herein we show that growth and photosynthetic performance are clearly linked to feeding, and that both processes diminish slowly over time and in relation to irradiance stress.

\section{MATERIALS AND METHDOS}

Culture and experimental conditions. Myrionecta rubra and Teleaulax acuta were isolated from McMurdo Sound, Antarctica, from a nutrient-enriched sample of sea ice and water collected in January 1996 (Gustafson et al. 2000). Cultures were grown in 11 glass flasks with 32 PSU F/2 -Si media (Guillard 1975), at 0 to $2^{\circ} \mathrm{C}$. For normal culture maintenance, M. rubra is fed the cryptophyte $T$. acuta periodically to maintain positive growth rates. In preparation for this experiment, cultures were acclimated to two $24 \mathrm{~h}$ light

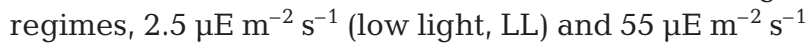
(high light, HL), for $3 \mathrm{mo}$, while only receiving fortnightly additions of $F / 2$ media. Thus cell populations were starved of $T$. acuta prey at the beginning of the experiment. The experiment was divided into 7 periods, whereby Period $1=$ Days 0 to 14 , Period $2=$ Days 15 to 28, etc. (see next paragraph for details).
At the beginning of the experiment, Myrionecta rubra cultures were fed Teleaulax acuta in Period 1 with $3838 \pm 107$ and $4399 \pm 698$ cells ml m $^{-1}$ and in Period 2 with $3162 \pm 21$ and $3066 \pm 350$ cells ml ${ }^{-1}$, for the HL and LL treatments, respectively (Fig. 1). While no short-term sampling was conducted to measure grazing kinetics in this experiment, previous experiments with this culture have shown ingestion rates of 1.3 prey $M$. rubra cell ${ }^{-1} \mathrm{~h}^{-1}$ and clearance rates of $128 \mathrm{nl} \mathrm{cell}^{-1} \mathrm{~h}^{-1}$ (Gustafson et al. 2000). M. rubra concentrations at Time $(t)=0$ were $1266 \pm 53$ and $1420 \pm$ 253 cells $\mathrm{ml}^{-1}$ in Period 1 and $718 \pm 83$ and $1244 \pm$ 171 cells $\mathrm{ml}^{-1}$ in Period 2, for HL and LL treatments, respectively. After Period 2, $M$. rubra cells were only given fresh $F / 2$ culture media every $2 \mathrm{wk}$ in order to establish starved cell populations (Fig. 1). Experimental treatments each had 3 replicates. Growth rates $(\mu)$ were estimated during the exponential portion of the growth phase using $\mu$ (divisions $\left.d^{-1}\right)=\left[\log _{2}\left(n_{1} / n_{0}\right)\right] / t_{1}-$ $\mathrm{t}_{0}$, where $n_{0}$ and $n_{1}$ are cell concentrations at the beginning and start of the exponential growth phase, respectively.

Cellular attributes. Cell volume was determined by measuring cell length and width using an ocular micrometer on a Nikon Eclipse inverted microscope at $100 \times$ magnification for at least 30 cells per replicate and time point. Cell volume $(V)$ was calculated using $V$ $\left(\mu \mathrm{m}^{3}\right)=(\pi / 6) \cdot w^{2} \cdot 1$, where $w$ is the cell width and $l$ the length. Cell concentrations and nuclei were enumerated by staining glutaraldehyde-fixed ( $1 \%$ final conc.) cells with the nucleic acid stain, 4,6-diamidino-2phenylindole (DAPI), and viewing cells at $100 \times$ magnification on a Nikon Eclipse compound microscope equipped with a fluorescent light source, and Nikon filter sets EF-4 B-2A (exciter filter 450 to $490 \mathrm{~nm}$; dichromatic beam splitter, DM, $500 \mathrm{~nm}$; barrier filter, $\mathrm{BA}, 515 \mathrm{~nm}$ ) and UV 2E/C (exciter filter 340 to $380 \mathrm{~nm}$; DM $400 \mathrm{~nm}$; BA 435 to $485 \mathrm{~nm}$ ). Chlorophyll a was extracted by filtering culture aliquots onto a GF/C filter

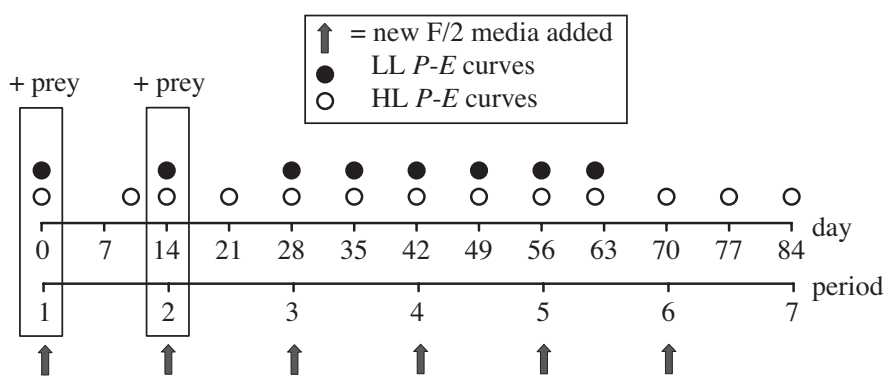

Fig. 1. Experimental schedule showing addition of Teleaulax acuta prey, new $F / 2$ media, and execution of photosynthesis vs. irradiance $(P-E)$ curves during experiment; $x$-axes illustrate relationship between periods ( 1 to 7 ) and days during experiment (see 'Materials and methods' for details). LL: low light treatment; HL: high light treatment 
and extracting overnight in $90 \%$ acetone at $-20^{\circ} \mathrm{C}$. Chlorophyll concentrations were determined using a Turner Designs model 10-AU fluorometer.

Chlorophyll a budget. Total ingested chlorophyll $\left(\mathrm{chl}_{\mathrm{I}}\right)$ per period was calculated by measuring removal of free-living prey chl using the equation:

$$
\left.\operatorname{chl}_{\mathrm{I}}=\left[\left(\mathrm{chl} a \mathrm{ml}^{-1}\right)_{\text {prey, } T=14}-(\mathrm{chl} \mathrm{a} \mathrm{ml})^{-1}\right)_{\text {prey, } T=0}\right] \cdot T^{-1}
$$

where $T$ is the total number of days per period; and chl a ml ${ }^{-1}$ was determined by multiplying chl a cell ${ }^{-1}$ and cells $\mathrm{ml}^{-1}$. The total chlorophyll a budget $\left(\mathrm{chl}_{\mathrm{B}}\right)$ for Myrionecta rubra (MR) was determined per period by using the equation:

$$
\operatorname{chl}_{\mathrm{B}}=\left[\left(\mathrm{chl} a \mathrm{ml}^{-1}\right)_{\mathrm{MR}, T=14}-\left(\mathrm{chl} a \mathrm{ml}^{-1}\right)_{\mathrm{MR}, T=0}\right] \cdot T^{-1}
$$

Total chlorophyll a production per period ( $\mathrm{chl}_{\mathrm{P}}$ ) was then determined using $\mathrm{chl}_{\mathrm{P}}=\mathrm{chl}_{\mathrm{B}}-\mathrm{chl}_{\mathrm{I}}$.

Photosynthesis $\left({ }^{14} \mathbf{C}\right)$ measurements. Photosynthesis vs. irradiance $(P-E)$ measurements (Lewis \& Smith 1983) were made on Days 7 and 14 of each 2 wk growth cycle, at $2^{\circ} \mathrm{C}$ using a photosynthetron connected to a chiller. During Periods 1 and 2 when Teleaulax acuta prey was present, $P-E$ measurements were only made when prey was at background levels (i.e. <100 cells $\mathrm{ml}^{-1}$ ) (Fig. 1). Culture aliquots were removed and kept on ice around midday, and $\mathrm{NaH}^{14} \mathrm{CO}_{3}{ }^{-}$was added to a final activity of $1 \mu \mathrm{Ci} \mathrm{ml}{ }^{-1}$. At $t=0$, controls were taken by adding $2 \mathrm{ml}$ of labeled culture immediately to a vial with $200 \mu \mathrm{l}$ of formalin, and used later for subtracting background levels of ${ }^{14} \mathrm{C}$ activity. Background and total activity controls were then placed in the dark at $4^{\circ} \mathrm{C}$ overnight. Samples for total activity were collected by adding $100 \mu \mathrm{l}$ of sample to $200 \mu \mathrm{l}$ of $\beta$-phenylethylamine (Sigma). ${ }^{14} \mathrm{C}$-spiked culture $(2 \mathrm{ml})$ was then added to $7 \mathrm{ml}$ scintillation vials, on ice, and immediately transferred to the chilled photosynthetron block. A total of 15 vials were used for each triplicate $P-E$ assay, and incubated for $30 \mathrm{~min}$ at constant irradiance between 0 and $800 \mu \mathrm{mol}$ photons $\mathrm{m}^{2} \mathrm{~s}^{-1}$. At the end of the incubation, the vials were acidified with $500 \mu \mathrm{l} 6 \mathrm{~N}$ $\mathrm{HCl}$ to remove unincorporated ${ }^{14} \mathrm{C}$, and placed on a shaker overnight at room temperature. In order to determine the ${ }^{14} \mathrm{C}$ activity of the vials, $4 \mathrm{ml}$ of Ultima Flo AP (Perkin Elmer) scintillation cocktail was added to the background control and light-exposed vials, while $5 \mathrm{ml}$ was added to the total activity vials. All ${ }^{14} \mathrm{C}$ incorporation and control activities were determined using a Tri-Carb 2200CA liquid scintillation counter (Packard Bioscience). Photosynthetic rates were determined using analytical methods described by Parsons et al. (1984), and $P-E$ data was normalized to hourly rates and either cell or chlorophyll a concentrations. Curve-fitting for $P-E$ data was conducted in Sigma Plot (SPSS software) using an equation based on that of Platt et al. (1980):

$$
P=P_{0}+P_{\mathrm{s}} \cdot\left\{1-\exp \left[(-E \cdot \alpha) / P_{\mathrm{s}}\right]\right\} \cdot \exp \left[(-E \cdot \beta) / P_{\mathrm{s}}\right]
$$

where $P=$ photosynthesis, $P_{0}$ is the $y$-intercept, $P_{\mathrm{s}}$ is the maximum potential rate of photosynthesis, $\alpha$ is the initial light-limited slope of the $P-E$ curve, $E$ is the irradiance, and $\beta$ is the slope of the photoinhibition region of the curve. From the curve-fitted data $\alpha, P_{\max }$ (maximum rate of photosynthesis), $I_{k}$ (photosynthesis-saturating light irradiance) $=P_{\max } / \alpha$, and $\beta$ were determined. $P_{\max }$ and $\alpha$ rates are presented both as cellular (e.g. $P_{\max (c e l l)}$ $=P_{\max } \cdot \mathrm{ml}^{-1}$ cells $\cdot \mathrm{ml}^{-1}$ ) and chlorophyll (e.g. $P_{\max (\mathrm{chl})}=$ $P_{\max (\mathrm{cell})} \mathrm{chl} \cdot \mathrm{cell}^{-1}$ ) normalized rates in this study.

Data analysis. Statistical analysis of cell attributes and $P-E$ parameter data were conducted using the mixed model ANOVA and multiple regression options in SAS/STAT 9.0 (SAS Institute), and p $<0.05$ as a level of significance. Comparisons for ANOVAs between means were made between treatments (HL vs. LL) and over time using Tukey's Studentized range (honest significant difference, HSD) test.

\section{RESULTS}

\section{Changes in cellular composition following feeding}

More than $95 \%$ of added prey were removed in both treatments by Day 14 for Periods 1 and 2 (Fig. 2A,B). Growth rates were highest while feeding, with the HL treatment reaching $0.19 \mathrm{~d}^{-1}$ and the LL treatment $0.11 \mathrm{~d}^{-1}$ (Fig. 2C). At the end of Period 2, Myrionecta rubra possessed 0.89 and 0.78 Teleaulax acuta nuclei cell $^{-1}$ in the HL and LL treatments, respectively (Fig. 3). Cell shape and volume were highly variable in the HL treatment when exposed to $T$. acuta prey. While the mean cell volume for HL cells over the course of the experiment was $4221 \mathrm{\mu m}^{3}$, maximum cell volume during Periods 1 and 2 reached 21435 and $13066 \mu^{3}$, respectively. These large cells, although rare, were sometimes irregularly shaped, with multiple ciliary bands arising from different regions of the cell, and possessing numerous ciliate macronuclei (mac) and micronuclei (mic) as well as T. acuta nuclei. Such cells were never observed in the LL treatment and may have been either an artifact due to higher light and/or cell division rates or perhaps due to sexual reproduction processes. LL cells averaged $3428 \mu^{3}$ during the entire experiment, and while maximum cell sizes reaching $13782 \mu^{3}$ during Period 4, cell shape remained regular and such large cells were rare.

\section{Changes in photophysiological parameters following feeding}

In both treatments, a dramatic rise in chl a cell ${ }^{-1}$ was observed following the introduction of prey (Fig. 4). 

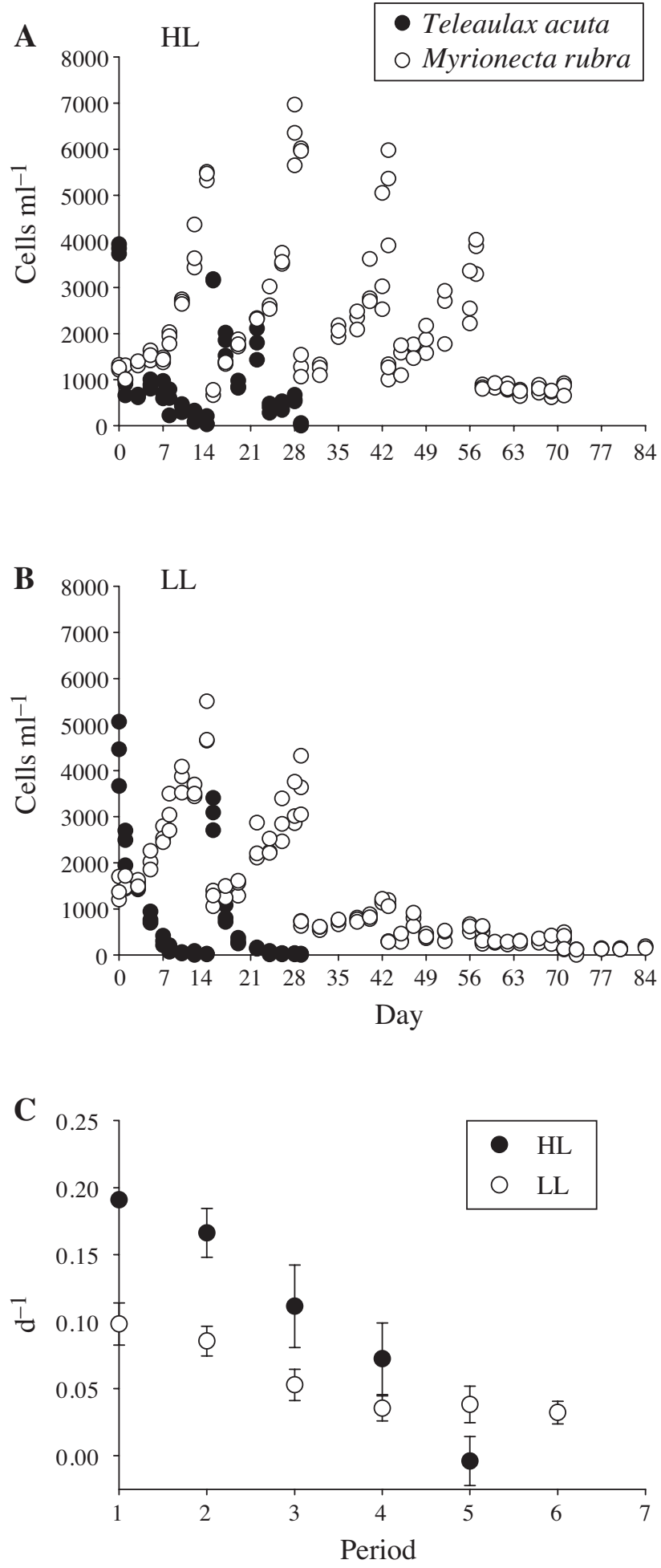

Fig. 2. Myrionecta rubra. Cellular concentration and growth rates during experiment in which $M$. rubra was initially fed Teleaulax acuta until Day 28 and then starved in HL and LL conditions with replete nutrients. (A,B) Concentration of $M$. rubra and Teleaulax acuta cells over time in (A) high and (B) low light; $(C)$ observed growth rates $(\mu)$ over time in HL and LL. Data points for (A) and (B) represent individual samples $(\mathrm{n}=3)$; data points for $(\mathrm{C})$ are means \pm SD. Periods as in Fig. 1

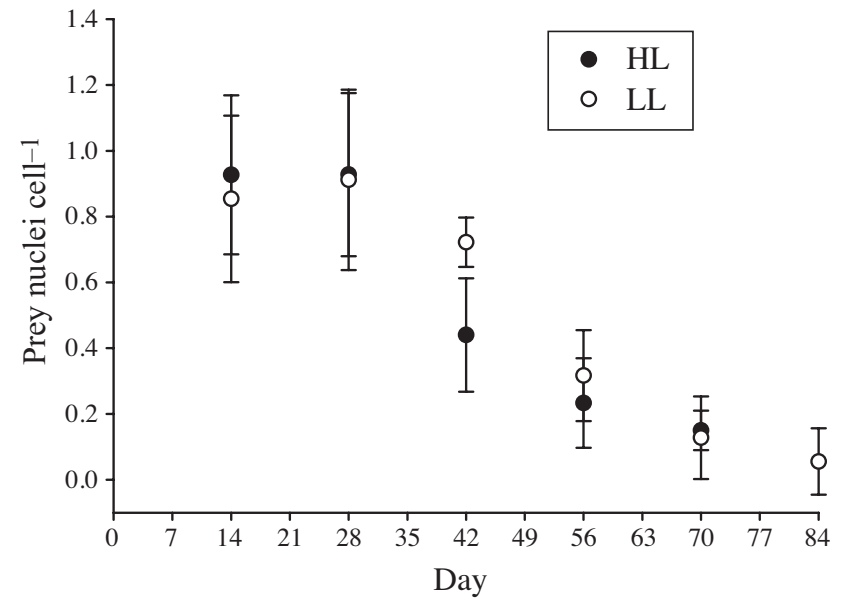

Fig. 3. Myrionecta rubra. Mean ( \pm SD) number of Teleaulax acuta (prey) nuclei per cell at end of each 2 wk growth period for HL and LL treatments. Experimental conditions as in Fig. 1

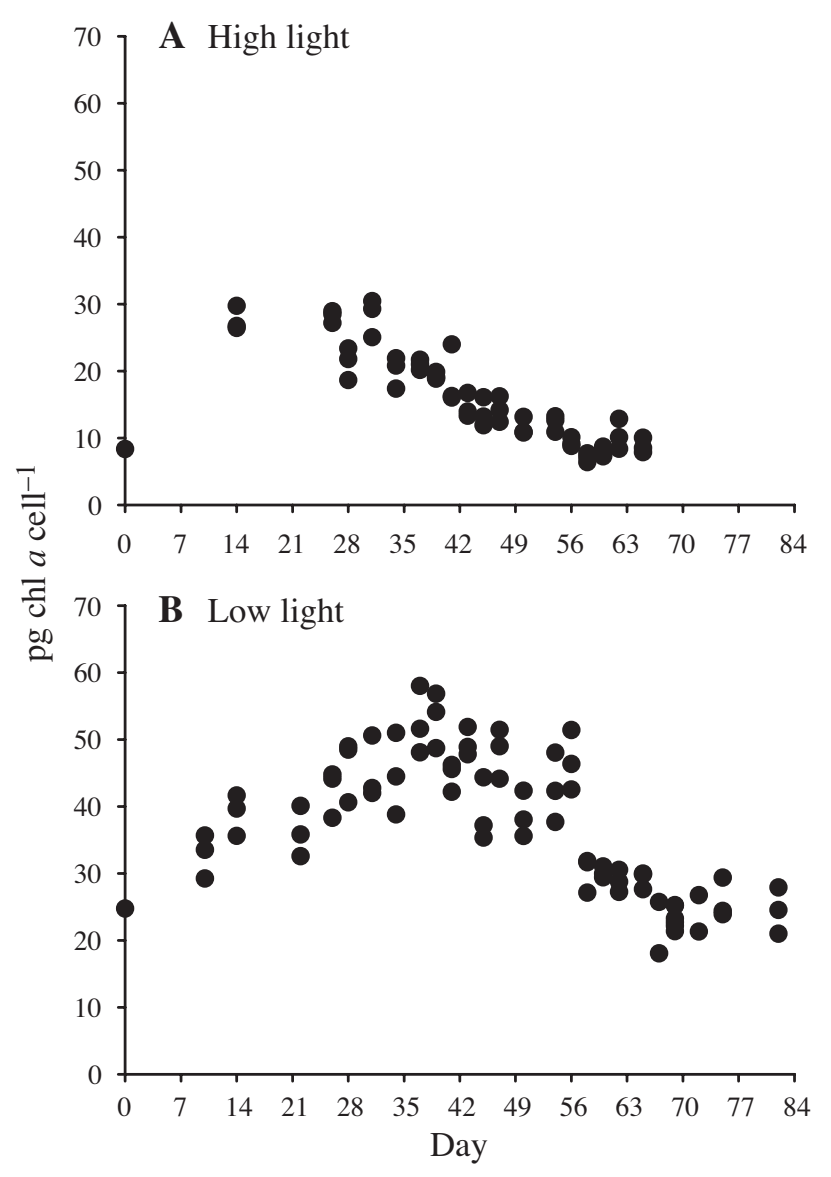

Fig. 4. Myrionecta rubra. Cellular concentrations of chlorophyll $a$ cell $^{-1}$ in (A) HL acclimated M. rubra and (B) LL acclimated M. rubra. Experimental conditions as in Fig. 2. Data points represent individual sample replicates 
This increase was more sustained in the LL treatment, with chl a cell ${ }^{-1}$ apparently reaching a transient steady state during Periods 3 and 4, averaging $45.9 \pm 5.8 \mathrm{pg}$ chl a cell ${ }^{-1}$ during this time, without addition of new prey. Chlorophyll budgets were determined in order to assess relative contributions from feeding vs. chl synthesis. Calculations of $\mathrm{chl}_{\mathrm{P}}$ for Myrionecta rubra during this study revealed that feeding is a minor source of chl

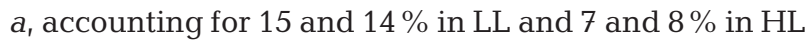

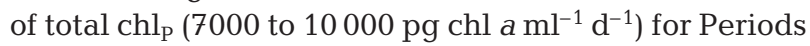
1 and 2 , respectively (Fig. 5). In the LL treatment, $P_{\max }$ (cell) increased during and after the feeding periods, reaching $46 \pm 4 \mathrm{pg} \mathrm{C}$ cell $^{-1} \mathrm{~h}^{-1}$, and closely mirroring trends in chl cell ${ }^{-1}$ during the experiment (Fig. 6A). HL chl cell ${ }^{-1}$ peaked at $28 \pm 3 \mathrm{pg} \mathrm{chl} \mathrm{a} \mathrm{cell}^{-1}$ but, unlike the LL treatment, these elevated concentrations were not maintained. HL $P_{\max (\text { cell) }}$ rates showed less variation and peaked at $21 \pm 3 \mathrm{pg} \mathrm{C}$ cell $^{-1} \mathrm{~h}^{-1}$ (Fig. 6A). In both treatments, $\alpha_{\text {cell }}$ increased after feeding to $0.55 \pm 0.08$ in the $\mathrm{HL}$ and $1.74 \pm 0.31 \mathrm{pg} \mathrm{C}(\mathrm{cell})^{-1}\left(\mu \mathrm{E} \mathrm{m}^{-2} \mathrm{~s}^{-1}\right)^{-1}$ in

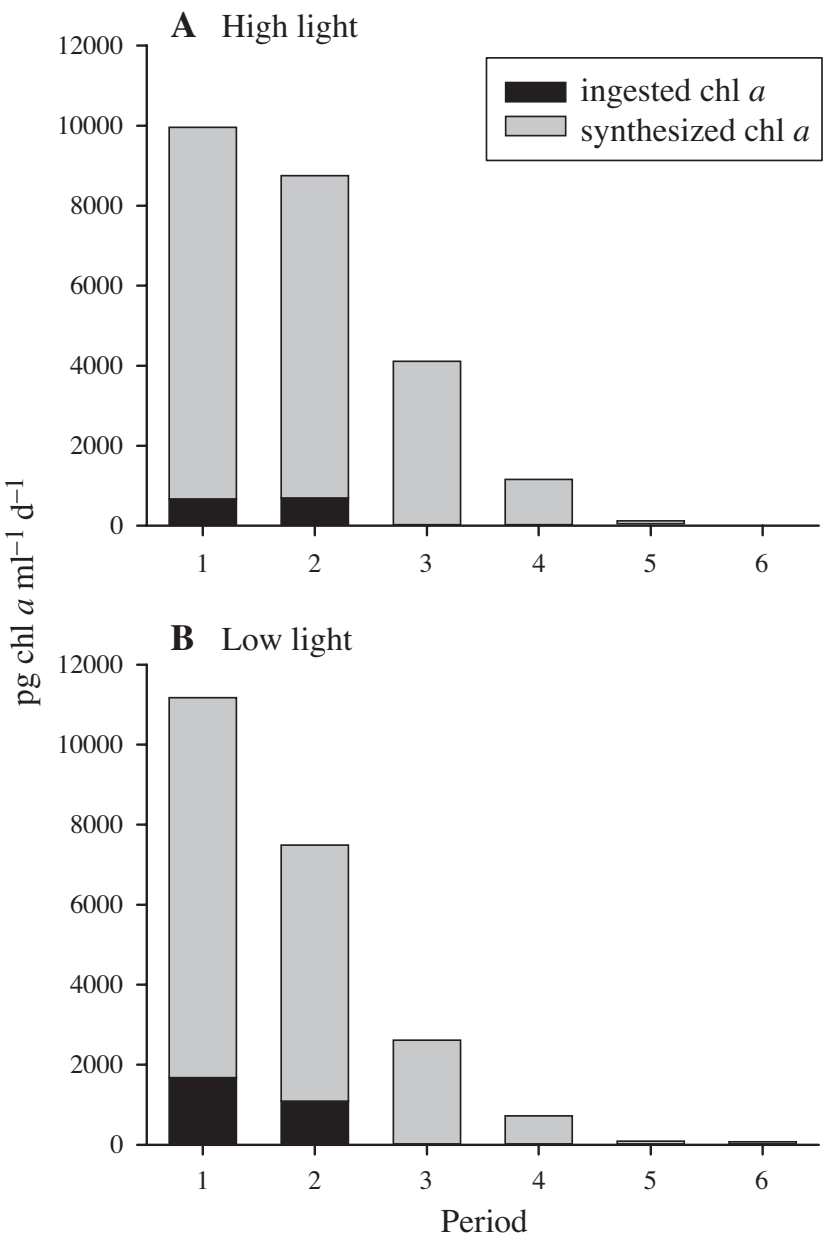

Fig. 5. Myrionecta rubra. Estimated chlorophyll a (chl a) production and chl a gained by ingestion of cryptophyte prey each 2 wk period. Periods as in Fig. 1; experimental conditions as in Fig. 2. Histograms represent sample means
LL (Fig. 6B). $P_{\max (\text { chl) }}$ steadily increased following feeding for both treatments, reaching a maximum of 1.18 and $1.46 \mathrm{pg} \mathrm{C}(\mathrm{pg} \mathrm{chl} a)^{-1} \mathrm{~h}^{-1}$ for LL and HL, respectively, while $\alpha_{\text {chl }}$ did not reveal any obvious trend after feeding (Fig. 7).

\section{Changes in cellular composition during starvation}

Following Period 2, no new prey was added to either treatment and changes in cell parameters were observed during starvation for 6 to 8 additional weeks.
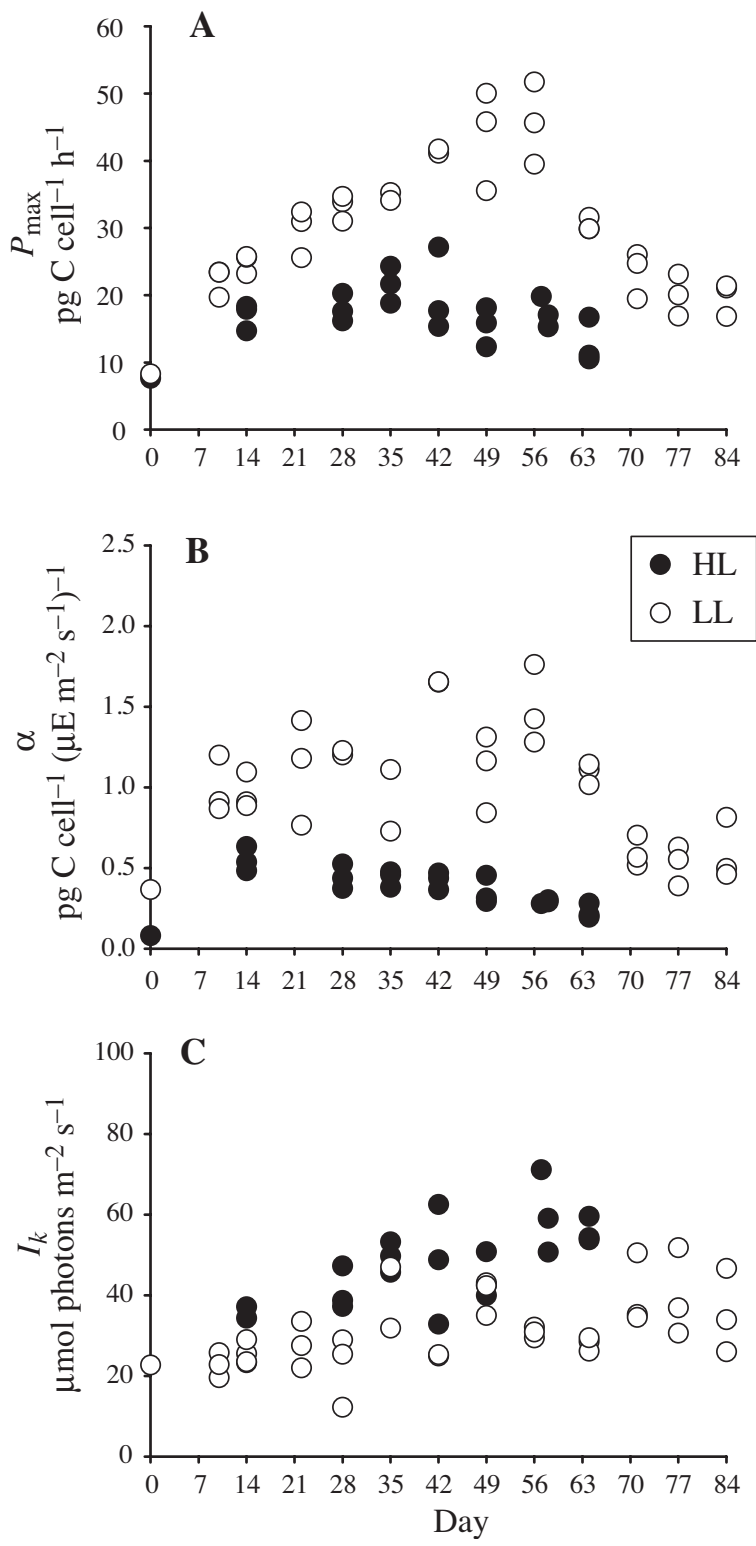

Fig. 6. Myrionecta rubra. Cell-specific photosynthesis vs. irradiance $(P-E)$ parameters. Experimental conditions as in Fig. 2. (A) Maximum rate of photosynthesis $\left(P_{\max (\mathrm{cell})}\right)$; (B) initial slope of $P-E$ curve $\left(\alpha_{\text {cell }}\right)$; $(C)$ light saturation parameter $\left(I_{k}\right)$ in HL and LL. Data points represent individual sample replicates 

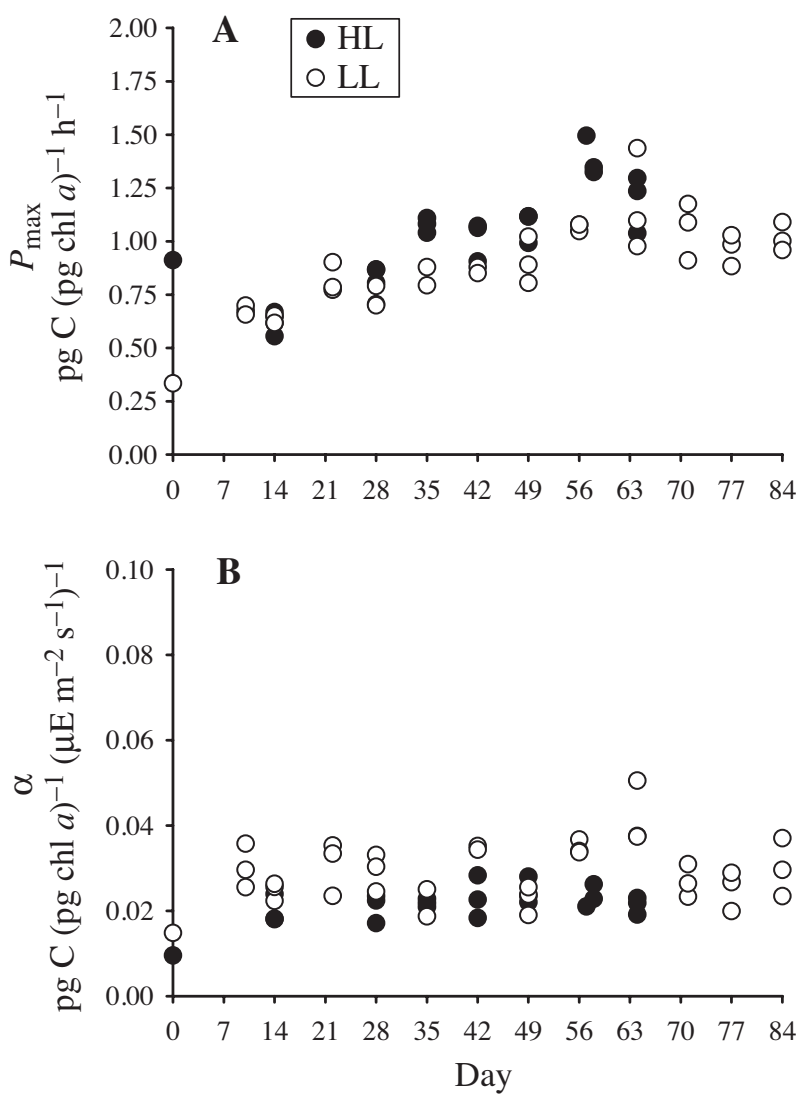

Fig. 7. Myrionecta rubra. Chlorophyll a-specific photosynthesis vs. irradiance $(P-E)$ parameters. Experimental conditions as in Fig. 2. (A) Maximum rate of photosynthesis $\left(P_{\max (\mathrm{chl})}\right)$; (B) initial slope of $P-E$ curve $\left(\alpha_{\text {chl }}\right)$. Data points represent individual sample replicates

The HL treatment was terminated after $6 \mathrm{wk}$ (total of 5 periods), since it contained too few cells, while the LL treatment was continued to $8 \mathrm{wk}$ past feeding or (total of 6 periods). Prey nuclei cell ${ }^{-1}$ declined in the absence of new prey, with under $10 \%$ of LL Myrionecta rubra cells possessing Teleaulax acuta nuclei by the final period (Fig. 3). After 4 wk without prey (Period 4), $\mu$ for both treatments of $M$. rubra declined by nearly half of fed growth rates to $0.072 \pm 0.026$ (HL) and $0.035 \pm 0.009$ (LL) $\mathrm{d}^{-1}$ (Fig. 2C). By $6 \mathrm{wk}$ of starvation (Period 5), no growth was observed in the HL treatment while $\mu$ remained relatively steady in the LL treatment through Period $6\left(\sim 0.035 \mathrm{~d}^{-1}\right)$. Cell volume slightly declined in the HL treatment over time and increased in the LL treatment (data not shown).

\section{Changes in photophysiological parameters during starvation}

Chl cell ${ }^{-1}$ remained at relatively constant levels in the LL treatment for about 4 wk following Period 2, despite no new additions of prey and positive growth rates for Myrionecta rubra. In the HL treatment, chl a cell $^{-1}$ continued to increase briefly in Period 3 (Days 28 to 42 ) and then steadily declined during starvation to near pre-feeding levels $\left(12.8 \pm 3.4 \mathrm{pg}\right.$ chl a cell $\left.{ }^{-1}\right)$ (Fig. 4A). In the LL treatment, chl a cell ${ }^{-1}$ also fell to pre-feeding levels $\left(19.8 \pm 2.6 \mathrm{pg} \mathrm{chl} \mathrm{a} \mathrm{cell}{ }^{-1}\right)$ by Period 6 (Days 70 to 84) (Fig. 4B). Declines in chl a cell ${ }^{-1}$ were reflected in measurements of $P_{\max (c e l l)}$ i however, this was more pronounced in the LL treatment (Fig. 6A). $\alpha_{\text {cell }}$ also declined during the starvation period. In the LL treatment, $\alpha_{\text {cell }}$ was highly variable; however, the pattern was similar to that observed for $P_{\max \text { (cell) }}$ (Fig. 6B). The HL treatment showed little variability in $\alpha_{\text {cell }}$ and, like $P_{\max (\text { cell), steadily declined with time. }}$ Increases in $P_{\max (\mathrm{chl})}$ reached a maximum during Period 5 (Days 56 to 70) for both treatments, at $1.36 \pm$ 0.12 and $1.22 \pm 0.27 \mathrm{pg} \mathrm{C}(\mathrm{pg} \mathrm{chl} a)^{-1} \mathrm{~h}^{-1}$ for the HL and LL, respectively, before leveling off in both treatments (Fig. 7A). $\alpha_{\text {chl }}$ showed no clear pattern for either treatment during the experiment (Fig. 7B). Data for the $\beta$ parameter (slope of light saturated portion of $P-E$ curve) revealed low levels of photoinhibition for the LL treatment [mean $\beta$ : $6.5 \times 10^{-5} \mathrm{pg} \mathrm{C}(\mathrm{pg} \mathrm{chl} \mathrm{a}) \mathrm{h}^{-1}$ ], while the HL treatment [mean $\beta:-1.07 \times 10^{-4} \mathrm{pg} \mathrm{C}(\mathrm{pg} \mathrm{chl} a)$ $\mathrm{h}^{-1}$ ] never reached photoinhibited levels (data not shown). Within both treatments, $\beta$ was highly variable, with no significant trend over time. However, overall $\beta$ between treatments was significantly higher in LL vs. HL through Periods 1 to 5 (paired $t$-test; $\mathrm{p}=0.0004$ ). The $I_{k}$ parameter continued to increase throughout the starvation period, nearly doubling values from Period 1 and reaching 60 and $40 \mu \mathrm{E} \mathrm{m} \mathrm{m}^{-2} \mathrm{~s}^{-1}$ for HL and LL treatments, respectively (Fig. 6C).

\section{DISCUSSION}

The physiology and survival strategy of Myrionecta rubra is unique. While other ciliated protists have been shown to sequester plastids and mitochondria from their prey (Johnson et al. 1995), none appear to retain prey nuclei or function completely as a phototroph. Plastidic ciliates are important members of marine and freshwater planktonic communities (Stoecker et al. 1987). In coastal marine and estuarine systems, $M$. rubra is frequently the dominant plastidic ciliate (e.g. Sanders 1995, Witek 1998, Sorokin et al. 1999) and the only species known to cause recurrent red water events. Other plastidic ciliates may also have high photosynthetic rates, but are predominantly mixotrophic (Stoecker et al. 1988). Putt (1990) found that most carbon acquired via photosynthesis in the oligotrich Laboea strobila was used for respiration, while ingested carbon was used primarily for growth. While 
many plastidic oligotrichs are obligate phototrophs, their plastids have short residence times (hours) and thus are highly dependent on phagotrophy not only for heterotrophic growth, but also for replacing aging chloroplasts (Stoecker \& Silver 1990). Clearly M. rubra is unique in this regard, in that it can grow phototrophically for long periods without prey, and has capacity for substantial, albeit transient, pigment synthesis.

The effects of ingesting cryptophyte prey upon the photophysiological capacity of Myrionecta rubra in this study were immediate and dramatic. Chl a cell ${ }^{-1}$ quickly increased for both HL and LL treatments when fed, and resulted in maximum observed $\mu$. The dramatic rise in chl a cell ${ }^{-1}$ and maintenance of elevated chl a concentrations without further addition of prey suggests a capacity for chl a synthesis in M. rubra, as shown previously by Gustafson et al. (2000). While elevated chl a cell ${ }^{-1}$ was maintained longer in LL, actual chl a production for both treatments was nearly identical (Fig. 5). The faster decline of chl a cell ${ }^{-1}$ in $\mathrm{HL}$ (Fig. 3) was most likely due to higher growth rates, and a lower acclimation state chl a quotient (i.e. for acclimation to high light). While it is possible that the more precipitous decline in chl a cell ${ }^{-1}$ and $\mu$ in HL treated cells were due to greater photooxidative stress than in LL cells, we have no evidence to support such a conclusion. Despite dramatic changes in chl a cell ${ }^{-1}$ over time, $\alpha_{\text {chl }}$ was relatively steady throughout the experiment for both treatments, suggesting no real loss in photosynthetic efficiency per unit chlorophyll over time (Fig. 7B). That $M$. rubra is able to grow phototrophically (i.e. in the absence of prey) while synthesizing chl a suggests at least some transient capacity for maintaining and repairing sequestered plastids. Interestingly, Teleaulax acuta nuclei were retained by $M$. rubra and remained within the cell population for up to $6 \mathrm{wk}$ into the starvation period. These nuclei apparently do not undergo division in $M$. rubra and, while $>90 \%$ of cells may contain them, after feeding the proportion of cells with prey nuclei is diluted through cell division. The absence of new prey and the eventual loss of prey nuclei from the population may have resulted in the loss of certain functions associated with plastid biosynthetic pathways, pigment synthesis and regulation.

As expected, highest rates for $P_{\max (\text { cell) }}$ and $\alpha_{\text {cell }}$ closely followed maximum chl a cell ${ }^{-1}$ levels, especially in the LL treatment. The photosynthetic rates measured here are somewhat modest for Myrionecta rubra, as previous measurements during blooms have shown extremely high chlorophyll-specific, light-saturated carbon assimilation rates of $>10 \mathrm{pg} \mathrm{C}(\mathrm{pg} \mathrm{chl} \mathrm{a})^{-1} \mathrm{~h}^{-1}$ (Smith \& Barber 1979). The reason for this discrepancy may be that our Antarctic strain is grown at 0 to $2^{\circ} \mathrm{C}$ $\left(P-E\right.$ curves at $\left.2^{\circ} \mathrm{C}\right)$ and in constant light, both of which may decrease light saturated rates of photosynthesis
(Cota et al. 1994). Indeed, light-saturated photosynthetic measurements of Antarctic $M$. rubra field populations are also relatively low, at $1.04 \mathrm{pg} \mathrm{C}\left(\mathrm{pg} \mathrm{chl} \mathrm{a)^{-1 }}\right.$ $\mathrm{h}^{-1}$, falling within the range of those presented here (Satoh \& Watanabe 1991). The increase in $I_{k}$ with time is also attributable to chl a cell ${ }^{-1}$ loss, and indicates a loss of steady state acclimation to experiment growth irradiance (Fig. 6C). During the experiment, $I_{k}$ remained at or below growth irradiance for the HL treatment, while $I_{k}$ was always higher than growth irradiance in LL. Overall, $I_{k}$ values were low, perhaps due not only to the relatively low growth irradiance used in this experiment, but also to adaptation to low temperature, as seen with polar algae (e.g. Cota et al. 1994).

Myrionecta rubra cells in this experiment appeared to be acclimated to their respective irradiance regimes and regulate chl a cell ${ }^{-1}$ levels to apparently optimize growth. While declines in $P_{\max (\text { cell) }}$ over time can simply be explained by decreasing chl a cell ${ }^{-1}$ during starvation, reasons for variation in $P_{\max (c h l)}$ are less obvious. The lower rates measured for $P_{\max (\mathrm{chl})}$ in the LL treatment suggest that under saturating irradiance LL cells experienced a greater packaging effect, i.e. inefficient chl a light absorption due to an abundance of chl a cell $^{-1}$. In fact, the steady increase in $P_{\max (\mathrm{chl})}$ over time, concurrent with losses of chl a cell-1, suggests that either both treatments experienced a packaging effect, or responded by up-regulating photochemistry. Nevertheless, increases in $P_{\max (\mathrm{chl})}$ for both treatments represented an increase in photosynthetic efficiency with time. For both treatments, the leveling off of $P_{\max (\mathrm{chl})}$ coincided with a new, lower chl a cell ${ }^{-1}$ steady state.

In this experiment, maximum chl a cell ${ }^{-1}$ and $P_{\max (\mathrm{chl})}$ levels occurred after Period 2 and were out of synchrony with maximum observed $\mu$, perhaps indicating that growth for Myrionecta rubra is greatest after sequestering new organelles from cryptophyte algae. Alternatively, this imbalance with photosynthesis and growth may suggest that mixotrophy enhanced growth rates while feeding. To evaluate the importance of ingesting prey carbon, we used $\mathrm{C} \mathrm{cell}^{-1}$ measurements of our Teleaulax acuta culture (unpubl. data) and observed prey removal $\left(\mathrm{d}^{-1}\right)$ during the first 2 periods. Maximum potential $\mathrm{C}$ contributions from ingestion were calculated as being 10.0 and $10.6 \%$ (for HL) and 10.8 and $8.8 \%$ (for LL), of total growth requirements in Periods 1 and 2, respectively. However, these calculations are probably gross overestimates as they assume total $\mathrm{C}$ assimilation and do not account for organelle retention. Therefore mixotrophic $\mathrm{C}$ gain from ingestion of cryptophyte prey does not account for the substantially higher growth rates observed when $M$. rubra is feeding. To further evaluate the C budget of $M$. rubra, we calculated carbon contributions from observed photosynthetic rates $\left(\mathrm{C}_{\mathrm{P}}\right)$, prey removal rates $\left(\mathrm{C}_{\mathrm{U}}\right)$ and 
estimated $\mathrm{C}$ cell ${ }^{-1}$ values $\left(\mathrm{C}_{\text {cell }}\right)$ (Menden-Deuer \& Lessard 2000) to calculate mixotrophic gross growth efficiencies $\left(\mathrm{GGE}_{\mathrm{M}}\right)$ during each period. Here we define $\mathrm{GGE}_{\mathrm{M}}$ as $\mathrm{G} / \mathrm{C}^{*} \cdot 100$, where $\mathrm{G}=\mathrm{C}_{\text {cell }}$. yield, and yield is the maximum population size during period (assuming no mortality) and $\mathrm{C}^{*}=\mathrm{C}_{\mathrm{P}}+\mathrm{C}_{\mathrm{U}}$. This estimate of $\mathrm{GGE}_{\mathrm{M}}$ is therefore based on mixotrophic growth, as it includes parameters for both phototrophy $\left(\mathrm{C}_{\mathrm{P}}\right)$ and heterotrophy $\left(\mathrm{C}_{\mathrm{U}}\right)$. During the feeding period, $\mathrm{GGE}_{\mathrm{M}}$ were greatest, suggesting some enhancement of $\mu$ associated with feeding, while during late starvation, $\mathrm{GGE}_{\mathrm{M}}$ declined, indicating an imbalance between $\mathrm{C}$ assimilation and growth (i.e. a $\mathrm{C}$ sink) (Fig. 8). Maximum $\mathrm{GGE}_{\mathrm{M}}$ values were 52 and $74 \%$ for the $\mathrm{HL}$ and LL treatments, respectively. During starvation, the decline in $\mathrm{GGE}_{\mathrm{M}}$ was dramatic in the HL treatment, approaching zero in Period 5, while the LL treatment was near $30 \%$ (Fig. 8). The total collapse of $\mu$ in the HL treatment, despite ongoing $C$ fixation, suggests that $M$. rubra loses anabolic functions related to photosynthesis when starved of cryptophyte prey for long periods, and that fixed $\mathrm{C}$ is either stored or excreted. The difference in rates of $\mathrm{GGE}_{\mathrm{M}}$ decline between treatments was perhaps due to greater photooxidative stress in the HL.

GGE for heterotrophic protists are generally between 40 and $60 \%$ (Caron \& Goldman 1990). Skovgaard (1998) compared the GGE of a heterotrophic dinoflagellate Gyrodinium sp., to that of the similar sized plastid retaining dinoflagellate, G. gracilentum, finding 23 to $27 \%$ higher GGE in G. gracilentum. While optimal net growth efficiency (i.e. for fixed C) for some phototrophs can exceed $80 \%$ (Herzig \& Falkowski 1989), plastid maintenance has been estimated to be a major energetic sink in phototrophs, requiring up to $50 \%$ of cell energy costs and resulting in lower growth rates

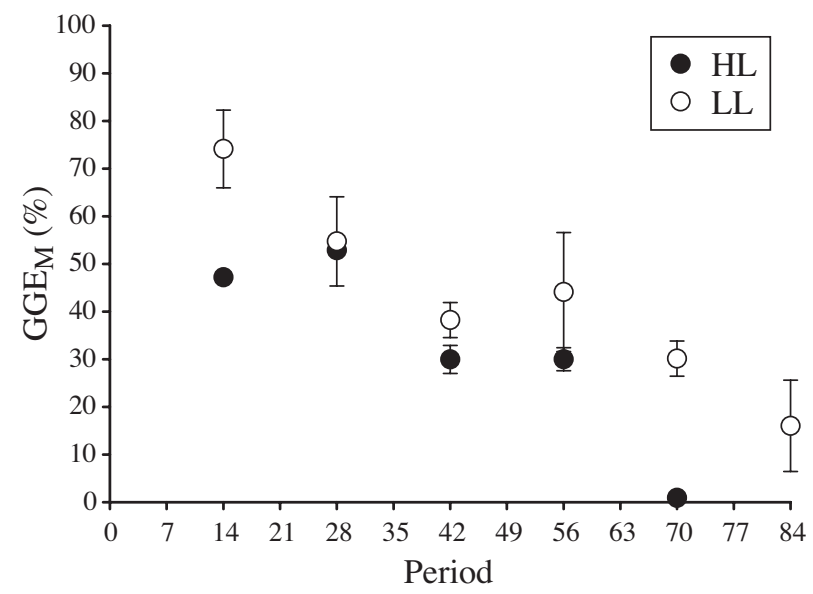

Fig. 8. Myrionecta rubra. Estimated mixotrophic gross growth efficiencies $\left(\mathrm{GGE}_{\mathrm{M}}\right.$; means $\left.\pm \mathrm{SE}\right)$ for combined autotrophic and heterotrophic growth. Experimental conditions as in

Fig. 2. GGE $_{\mathrm{M}}$ estimated for each 2 wk period (see Fig. 1) compared to heterotrophs (Raven 1997). Thus, in kleptoplastidic protists photosynthesis may be viewed as a luxury carbon source, resulting in higher GGE (e.g. Skovgaard 1998), and perhaps causing cells to endure periods of limited prey availability (e.g. Blackbourn et al. 1973). When feeding and sequestering new plastids, Myrionecta rubra may benefit from reduced costs associated with plastid maintenance, and thus have higher growth rates. However, because M. rubra is capable of plastid division and long-term phototrophic growth, it does not gain a free photosynthetic 'ride' as do other kleptoplastidic protists. Using data from Skovgaard (1998) we calculated $\mathrm{GGE}_{\mathrm{M}}$ for $\mathrm{G}$. gracilentum to be $\sim 48 \%$ in high irradiance $\left(90 \mu \mathrm{mol}\right.$ photons $\mathrm{m}^{-2}$ $\mathrm{s}^{-1}$ ). While this value is comparable to those obtained here for $M$. rubra, plastids in G. gracilentum were determined to be useful for only $\sim 2$ d (Skovgaard 1998). These comparisons underscore the paradoxical nature of $M$. rubra. While it functions as a phototroph and has the capacity to synthesize chl $a$, it occasionally requires ingestion of prey to sequester new organelles. Thus, M. rubra defies comparison with most other functional classifications for protists.

We have shown that while Myrionecta rubra attains higher growth rates under HL conditions, cell populations have longer sustained growth under LL conditions. Under low temperature conditions such as those used in this study, respiration rates would be relatively low (Caron et al. 1990), and therefore survival under prolonged starvation might be longer than that expected for cells grown at higher temperatures. Low respiration rates under polar conditions and the ability, shown here, of $M$. rubra to survive and even grow at low photosynthetically active radiation levels (PAR), may explain how populations of $M$. rubra can remain active during winter in certain regions of Antarctica. During winter in Ace Lake, a brackish lake in Antarctica, PAR at $2 \mathrm{~m}$ under ice is $<1 \mu \mathrm{E} \mathrm{m} \mathrm{m}^{-2} \mathrm{~s}^{-1}$, and active populations of $M$. rubra have been shown to occur at densities of up to 80 cells $\mathrm{ml}^{-1}$. Studies in temperate regions have shown $M$. rubra cells to form discrete layers at great depths (Setälä \& Kivi 2003). Furthermore, recurrent blooms of this ciliate have been shown to occur at dynamic boundaries in various upwelling regions (i.e. Ryther 1967), or following stratification in partially mixed estuaries (i.e. Crawford et al. 1997) or in fjords (i.e. Fenchel 1968, Lindholm 1978) around the world. These observations and the photophysiological measurements shown herein suggest that $M$. rubra may be adapted for survival under low light conditions, while thriving for shorter periods in high light. In conclusion, while feeding on cryptophyte algae ultimately limits growth and photosynthetic performance in $M$. rubra, the ciliate is able to function for long periods as a phototroph before feeding again. 
Acknowledgements. We thank J. Adolf for comments on this manuscript, D. Gustafson for technical assistance during the project, and the comments of 2 anonymous reviewers. This research was funded by NSF award INB-0131847. UMCES contribution 3850 .

\section{LITERATURE CITED}

Blackbourn DJ, Taylor FJR, Blackbourn J (1973) Foreign organelle retention by ciliates. J Protozool 20:286-288

Caron DA, Goldman JC (1990) Protozoan nutrient regeneration. In: Capriulo GM (ed) Ecology of marine Protozoa. Oxford University Press, New York, p 283-306

Caron DA, Goldman JC, Fenchel T (1990) Protozoan respiration and metabolism. In: Capriulo GM (ed) Ecology of marine Protozoa. Oxford University Press, New York, p 307-322

Cota GF, Smith WO Jr, Mitchell BG (1994) Photosynthesis of Phaeocystis in the Greenland Sea. Limnol Oceanogr 39: 948-953

Crawford DW (1989) Mesodinium rubrum: the phytoplankter that wasn't. Mar Ecol Prog Ser 58:161-174

Crawford DW, Purdie DA (1992) Evidence for avoidance of flushing from an estuary by a planktonic, phototrophic ciliate. Mar Ecol Prog Ser 79:259-265

Crawford DW, Purdie DA, Lockwood APM, Weissman P (1997) Recurrent red-tides in the Southampton Water Estuary by the phototrophic ciliate Mesodinium rubrum. Estuar Coast Shelf Sci 45:799-812

Dolan JR, Marrasé C (1995) Planktonic ciliate distribution relative to a deep chlorophyll maximum: Catalan Sea, NM Mediterranean, June 1993. Deep-Sea Res I 42:1985-1987

Fenchel T (1968) On 'red water' in the Isefjord (inner Danish waters) caused by the ciliate Mesodinium rubrum. Ophelia 5:245-253

Gibson JAE, Swalding KM, Pitman TM, Burton HR (1997) Overwintering populations of Mesodinium rubrum (Ciliophora: Haptorida) in lakes of the Vestfold Hills, East Antarctica. Polar Biol 17:175-179

Guillard RRL (1975) Culture of phytoplankton for feeding to marine invertebrates. In: Smith WL, Chanley MH (eds) Culture of marine invertebrate animals. Plenum Publishing, New York, p 29-60

Gustafson DE, Stoecker DK, Johnson MD, Van Heukelem WF, Sneider K (2000) Cryptophyte algae are robbed of their organelles by the marine ciliate Mesodinium rubrum. Nature 405:1049-1052

Hayes GC, Purdie DA, Williams JA (1989) The distribution of ichthyoplankton in Southampton Water in response to low oxygen levels produced by a Mesodinium rubrum bloom. 1989. J Fish Biol 34:811-813

Herzig R, Falkowski PG (1989) Nitrogen limitation in Isochrysis galbana (Haptophyceae). I. Photosynthetic energy conversion and growth efficiencies. J Phycol 25:462-471

Hibberd DJ (1977) Observations on the ultrastructure of the cryptomonad endosymbiont of the red water ciliate Mesodinium rubrum. J Mar Biol Assoc UK 57:45-61

Horstman DA (1981) Reported red-water outbreaks and their effects on fauna of the west and south coasts of South Africa, 1959-1980. Fish Bull S Afr 15:71-88

Jankowski AW (1976) Revision of the classification of the cyrtophorids. In: Markevich AP, Yu I (eds) Materials of the II All-Union Conference of Protozoology. Part I. General protozoology. Naukova Dumka, Kiev, p 167-168

Johnson PW, Donaghay PL, Small EB, Sieburth J McN (1995) Ultrastructure and ecology of Perispira ovum (Ciliophora:
Litostomatea): an anaerobic, planktonic ciliate that sequesters the chloroplasts, mitochondria and paramylon of Euglena proxima in a micro-oxic habitat. J Eukayot Microbiol 42:323-335

Lewis MR, Smith JC (1983) A small volume, short-incubation-time method for measurement of photosynthesis as a function of incident irradiance. Mar Ecol Prog Ser 13: 99-102

Lindholm T (1978) Autumnal mass development of the 'red water' ciliate Mesodinium rubrum in the Åland archipelago. Mem SFF (Soc Fauna Flora Fenn) 54:1-5

Lindholm T (1985) Mesodinium rubrum-a unique photosynthetic ciliate. Adv Aquat Microbiol 3:1-48

Lindholm T, Lindroos P, Mörk AC (1990) Depth maxima of Mesodinium rubrum (Lohmann) Hamburger and Buddenbrock - examples from a stratified Baltic Sea inlet. Sarsia 75:53-64

Menden-Deuer S, Lessard EJ (2000) Carbon to volume relationships for dinoflagellates, diatoms, and other protist plankton. Limnol Oceanogr 45:569-579

Oakley BR, Taylor FJR (1978) Evidence for a new type of endosymbiotic organization in a population of the ciliate Mesodinium rubrum from British Columbia. Bio Systems 10:361-369

Packard TT, Blasco D, Barber RT (1978) Mesodinium rubrum in the Baja California upwelling system. In: Boje R, Tomczak M (eds) Upwelling ecosystems. Springer-Verlag, Berlin, p 73-89

Parsons TR, Maita Y, Lalli CM (1984) A manual of chemical and biological methods for seawater analysis. Pergamon Press, Oxford

Passow U (1991) Vertical migration of Gonyaulax catenata and Mesodinium rubrum. Mar Biol 110:455-463

Platt T, Gallegos CL, Harrison WG (1980) Photoinhibition of photosynthesis in natural assemblages of marine phytoplankton. J Mar Res 38:687-701

Putt M (1990) Metabolism of photosynthate in the chloroplastretaining ciliate Loboea strobila. Mar Ecol Prog Ser 60: 271-282

Raven JA (1997) Phagotrophy in phototrophs. Limnol Oceanogr 42:198-205

Ryther JH (1967) Occurrence of red water off Peru. Nature 214:1318-1319

Sanders RW (1995) Seasonal distributions of the photosynthesizing ciliates Laboea strobila and Myrionecta rubra (= Mesodinium rubrum) in an estuary of the Gulf of Maine. Aquat Microb Ecol 9:237-242

Satoh H, Watanabe K (1991) A red-water bloom caused by the autotrophic ciliate, Mesodinium rubrum, in the austral summer in the fast ice area near Syowa station, Antarctica, with note on their photosynthetic rate. J Tokyo Univ Fish 78:11-17

Setälä O, Kivi K (2003) Planktonic ciliates in the Baltic Sea in summer: distribution, species association, and estimated grazing impact. Aquat Microb Ecol 32:287-297

Skovgaard A (1998) Role of chloroplast retention in a marine dinoflagellate. Aquat Microb Ecol 15:293-301

Smith WO Jr, Barber RT (1979) A carbon budget for the autotrophic ciliate Mesodinium rubrum. J Phycol 15: 27-33

Sorokin YI, Sorokin PY, Ravagnan G (1999) Analysis of lagoonal ecosystems in the Po River Delta associated with intensive aquaculture. Estuar Coast Shelf Sci 48:325-341

Stoecker DK, Silver MW (1990) Replacement and aging of chloroplasts in Strombidium capitatum (Ciliophora: Oligotrichida). Mar Biol 107:491-502

Stoecker DK, Michaels AE, Davis LH (1987) Large proportion 
of marine planktonic ciliates found to contain functional chloroplasts. Nature 326:790-792

Stoecker DK, Silver MW, Michaels AE, Davis LH (1988) Obligate mixotrophy in Loboea strobila, a ciliate which retains chloroplasts. Mar Biol 99:415-423

Stoecker DK, Putt M, Davis LH, Michaels AE (1991) Photosynthesis in Mesodinium rubrum: species-specific measurements and comparison to community rates. Mar Ecol Prog Ser 73:245-252

Taylor FJR, Balckbourn DJ, Blackbourn, J (1969) Ultrastructure of the chloroplasts and associated structures within the marine ciliate Mesodinium rubrum (Lohmann). Nature 224:819-821

Editorial responsibility: David A. Caron, Los Angeles, California, USA
Taylor FJR, Blackbourn DJ, Blackbourn J (1971) The red-water ciliate Mesodinium rubrum and its 'incomplete symbionts': a review including new ultrastructural observations. J Fish Res Board Can 28:391-407

Wilkerson FP, Grunseich G (1990) Formation of blooms by the symbiotic ciliate Mesodinium rubrum: the significance of nitrogen uptake. J Plankton Res 12:973-989

Witek M (1998) Annual changes of abundance and biomass of planktonic ciliates in the Gdansk Basin, Southern Baltic. Int Rev Gesamten Hydrobiol 83:163-182

Yih W, Kim HS, Jeong HJ, Myung G, Kim YG (2004) Ingestion of cryptophyte cells by the marine photosynthetic ciliate Mesodinium rubrum. Aquat Microb Ecol 36:165-170

Submitted: November 2, 2004; Accepted: March 7, 2005 Proofs received from author(s): June 13, 2005 